\title{
Hookup Culture: The High Costs of a Low "Price" for Sex
}

\author{
Steven E. Rhoads
}

Published online: 18 October 2012

(C) Springer Science+Business Media New York 2012

In his piece, "Contemporary Mating Market Dynamics, SexRatio Imbalances, and Their Consequences," Mark Regnerus is right to emphasize that sex ratios are extremely important in determining whether men's or women's mating preferences are more likely to be honored. Now that women outnumber men on college campuses, they must compete among themselves by giving men more of what men want if they expect to find male companionship on Saturday night. Women are still the gatekeepers who determine how physical things will get, but, as Regnerus says, they have much more limited choices these days.

But Regnerus points out that even non-college men and post-college men get sex with more women than they used to. Sex ratios in the broader society are not so skewed as they are in college; so, why do men have more relationship power everywhere these days? Maybe there are also more marriageable men than women in the broader society once one subtracts all the disproportionately male homeless and criminal. But the homeless and criminal were always disproportionately male. What has changed? Why did women used to get wooed far more than they are today?

In his conclusion, Regnerus says "what scholars and journalists have described as the 'hook-up culture' that has emerged both on and off (and after) college campuses today, I assert, has little to do with sexual culture change, and far more to do with the bifurcated mating market and the sexratio imbalances that have emerged therein." But wasn't there always a bifurcated mating market? Collegiate men in the fifties would have been interested in sleeping with a variety of women on weekends just as they are today, but few attractive, educated women were available for those

\section{S. E. Rhoads $(\square)$}

Department of Politics, University of Virginia,

161S Gibson, PO BOX 400787, Charlottesville,

VA 22904-4787, USA

e-mail: ser6f@virginia.edu sorts of encounters. Now they are. The sexual culture has changed. The collegiate women are available because most of the women's movement has insisted that sexual liberation is an important part of women's liberation and because the Pill seemed to make sexual liberation costless.

If equal proportions of men and women were interested in casual sex on the one hand and in committed sex on the other, the bifurcated markets would not be problematic for women. The problem is not the new arrival of bifurcated markets, but rather the enduring fact that, despite all the huffing and puffing of androgynous feminists, casual sex is not a good fit for women's natures.

For the past 14 years, I have taught a college course on sex differences to juniors and seniors. When we talk about relationships and sex, the vast majority of the women seem very unhappy with the dominant hookup culture. In their papers and in class, time and again, they talk about their girlfriends' post-hookup traumas, even if they manage to avoid them themselves. If the men who these women hook up with do call again, they often only want more hookups, and, as soon as the women push for a real relationship, the men break it off.

I asked one senior who had been a resident advisor for freshmen for two academic years to write up her observations about the college hookup culture. She thought one of her friend's observations echoed many of the chastened freshmen women when she told her, "I hate this feelingthe pressure to sell my body to men, to dress scandalously just to get their attention, just to get them to notice me. Then all they want is a one night stand; they will use me for sex and don't give a shit about me as a person. They don't want to get to know me at all! I keep getting into it, I keep thinking I'll find someone this way-but I only get used every time."

The resident advisor concluded, "even females who try very hard to follow the male example with regard to sex are 
at a loss. ... Most of my female friends have tried being in purely physical relationships; not one of them lasted for more than a month. However, we are constantly told that we should be able to enjoy our sexuality with or without a relationship, just like men. When it comes to sex we are encouraged to do what we want, provided we protect ourselves from STDs and pregnancy. Yet we are not taught how to protect ourselves emotionally."

In 2010, together with two college female seniors, I wrote an article for the Chronicle (the online version of the Chronicle of Higher Education) that presented evidence showing that my female students' reactions to casual sex were not idiosyncratic. What is remarkable is that even women who write books about their sexual adventures and want to defend or even tout their sexual freedom end up telling the same story. In The Morning After: Sex, Fear, and Feminism (1994), Katie Roiphe speaks of feeling "almost sick with the accumulated anonymity of it, the haphazardness, the months and months of toweled men." In Lip Service (1997), Kate Fillion recounts how she retroactively decided she was in love with every man she had had sex with and how the power she got from sex "was the power to cause myself emotional pain." Cindy Chupack, an executive producer and writer for the HBO series "Sex and the City," gives us the details of her sexual escapades in The Between Boyfriends Book (2004), but confesses that she wants to be more than "a notch in somebody's bedpost"; she is looking for a husband.

None of this would surprise John Townsend, an evolutionary anthropologist whose extensive research has led him to conclude that women often go through an experimental stage where they try casual sex, but they almost always end up rejecting it. According to Townsend, for women, intercourse produces feelings of "vulnerability" and of being used when they cannot get the desired emotional investment from their partners. In Townsend's studies, these feelings occur even in the most sexually liberated women. Despite this group's free-thinking attitudes, their emotions make it impossible for them to enjoy casual sex.

Like other evolutionists, Townsend hypothesizes that men are more eager for sex than women because eons ago men with powerful sexual urges passed on their genes in greater numbers than men with moderate or low inclinations for sex. Men back then also would want sex with lots of mates because more mates would mean more offspring. In contrast, women who took advantage of any and every sexual opportunity would not produce children who thrived as well as choosier women. Women who mated with unusually strong or healthy men or men willing to commit ample resources to their children's needs would increase their children's likelihood of survival. Thus, through the ages, women with such tastes would be more apt to reproduce and rear their offspring successfully. Although some of the tastes and preferences that enhanced the survival of our ancestors in the past make less sense today, according to evolutionary psychology, these same tastes and preferences remain part of our genetically inherited psychological makeup and affect our decisions even when we are unaware of them.

Other social scientists report the same sex differences that Townsend does. Edward S. Herold and Dawn-Marie Mewhinney found that females who hook up get less enjoyment and feel more guilt than men do. Denise Hallfors and colleagues found that female teens are many times more likely than male teens to become depressed after sexual encounters with multiple partners. Catherine Grello, a clinical psychologist, and colleagues found that the college men who sleep around the most are the least likely to report symptoms of depression whereas female college students who engage in casual sex the most are the most likely to report depression.

In their book, Premarital Sex in America, Regnerus and coauthor Jeremy Uecker report that having more sexual partners is associated with "poorer emotional states in women, but not in men." The more lifetime partners the women have, the more likely they are to be depressed, the more likely they are to cry almost every day and the more likely they are to report relatively low satisfaction with their life as a whole. Paul Chara and Lynn Kuennen's research seems to support the female souring effect that Townsend found. Chara and Kuennen asked young women and men in high school and college whether they would be willing to engage in sex after a wonderful first date. On average, college seniors are certainly more sexually experienced than ninth graders. Yet $30 \%$ of the ninth grade women said they would be game for sex after that great first date while only $5 \%$ of college senior women said they would be. The trend for young men was the opposite. About $30 \%$ of the ninth grade boys said they would have sex after the great first date, but fully $60 \%$ of the college senior men said they would do so.

My female students tell me that the emotional pain that casual sex causes women goes largely unreported because the women are often ashamed that they care about men who treat them like strangers the next morning. These women don't want the men involved or the rest of the campus to know about their tears.

Our Chronicle article prompted some private correspondence with a sociologist who thought the magnitude of the gender differences in emotional costs of casual sex was relatively small. More generally, she thought, "in the industrialized West we may be nearing the very first point in human history [when] social and physical costs associated with women's promiscuity are lowered enough to actually get a chance to see what women would do and like if not constrained by fears of pregnancy, childbearing or social stigma."

So, we know that since the beginning of recorded history, it is men not women who are eager enough to have sex with 
a variety of women that they hire prostitutes. We know that in the privacy of their bedrooms, men consume pornography presenting a variety of quasi-anonymous female bodies, while women consume romance novels in which sex occurs with a special man who feels an all-consuming love for the heroine. We know that, if space allowed, there is far more research that could be offered supporting the position that men like casual sex more than women. Some of this research is so cross-cultural that it bears titles such as "Universal Sex Differences in the Desire for Sexual Variety: Tests from 52 Nations, 6 Continents, and 13 Islands." Moreover, we now have had three generations of young women come of age since the sexual revolution. But still, we are told, it is too soon to come to any conclusions about women's sexual nature. We need more time. Such is the power of the dominant paradigm - sex differences are to be seen as gender differences, small and socially constructed.

I wish Regnerus had qualified his argument less broadly. He writes: "many, many women don't mind this new sexual economy" and "plenty of them like to spend some time in less-serious relationships." "Plenty" in absolute terms or relative terms? It's a big country. There could be plenty, and it could still be only a small fraction of the number of men who like casual sex.

Testosterone raises the libido, and there is reason to think that, on average, women who are the most attracted to casual sex have above average testosterone for their sex. The women Townsend studied who had the most casual sex experience had characteristics that have been associated with high testosterone. They competed in traditionally male sports and rejected traditional female roles and sexual morality. Because they found "sex outside of marriage totally acceptable," they were "shocked by their intense emotional reactions to their experiences. They honestly believed that they could enjoy sexual relations that involved little investment from their partners. They did not expect these emotions, could not understand them, and were surprised and disturbed by their inability to control them. These feelings were not part of their sex-role ideology and that is why the women were caught off guard."

Regnerus says "It's not true, of course, that starry-eyed women are now simply being more efficiently duped or hoodwinked by skirt-chasing, commitment-phobic men." Does he really know from his findings that the women who have had the most lifetime partners and who are now crying almost every day did not begin with high hopes for romance with the men they spent time with? The Halfors study, mentioned above, finds in its sample of pre-college youth that sleeping with multiple men comes first and depression second. At the University of Virginia, my classes tell me that freshmen women are more likely to participate in the hookup scene than upper class women. I'm told that some frat boys call the freshmen coeds "fresh meat" and think they are more easily charmed into bed.
When Regnerus says "most women tend to prefer (and are more apt to enjoy) sex in stable, committed, romantic relationships," does he mean "most" or a "very large majority"? If "most" women prefer committed sex, but "plenty" prefer less serious sex, it's hard to see why the bifurcated markets are the grim problem for women that he says they are. Regnerus believes that as women age, they become concerned about commitment phobic men and their declining fecundity. This makes it sound as if women are not troubled by casual sex until they are in their thirties. Townsend and I believe instead that women are troubled by the time they are college seniorsor before if they have had many sexual partners. It is past time to repeat Townsend's research - to see whether, casual sex is only attractive to a substantial proportion of women during an experimental period.

Regnerus says that "the sky is not falling"; it is true that the hookup culture will not lead to a cosmological catastrophe. But is it a "big deal"? I think it is. I suspect that Regnerus does as well, but an exceedingly cautious tone on this subject is necessary for a young scholar trying to make his way in sociology.

Regnerus is right to link the hookup culture with nonmarital child births and to argue that women would not choose an ever lengthening and circuitous journey to marriage. Since children brought up by their biological parents tend to fare much better than with other arrangements, our society should want the mating market to reflect women's preferences far more than it does now.

In what follows, I will have more to say about how casual sex affects women. But when considering here broader societal effects, it is important to talk about how the hookup culture affects men. There is much discussion these days about young men's failure to thrive. But the discussions rarely mention sex.

We know that young men used to be willing to settle down with one woman and raise a family. They used to be willing to answer to a boss for 40 to 50 hours a week for 40 to 50 years. But men hate to be told what to do. Why, then, did they become reliable partners and providers often answering to their wives as well as their bosses? Perhaps because they could not get appealing women to pay attention to them unless they had "prospects." Men had to be marriageable and ready to commit or most women would not have sex with them. Most men still want marriage in a distant future, but they see no reason not to partake of the bodily charms of many attractive women in the meantime. To bed these women at their age in this age, men find that good pectoral muscles (thus time in the gym) are at least as useful as good career prospects (time in the library).

It will be not be easy to weaken the casual sex culture. But here are some places to start:

Sex education Women in my classes do know that they are more likely than male peers to have an unwanted pregnancy 
after sexual intercourse! But it seems half or more have never been told of other relevant facts about sex-and not just about the emotional costs of casual sex. They generally do not know that they're much more likely than men to get a sexually transmitted disease from contact with an infected partner; that they're much more likely than males to become infertile if they are infected; that the birth control pill dampens their sexual interest and pleasure; or that the Pill scrambles sensory (sub-conscious smell) messages, making them more attracted to men with immune systems similar to theirs rather than immune systems unlike theirs. The scrambled signals are a risk factor should one fall in love with a man while on birth control pills. If a woman marries the man and tries to have children with him, she will have somewhat higher odds of repeated miscarriages and perhaps of having more vulnerable offspring. Current "just the facts" sex education ignores important facts that young women have a right to know.

Student Health Services As explained in the book Unprotected, the student health services on most college campuses do a woefully bad job of addressing the problems for women arising from casual sex.

Women's Centers There are few questions that college women ponder with more concern than what to do about invitations to have sex. Women's Centers could provide an invaluable service if they provided forums and counseling addressing the subject. On a number of occasions I've asked my classes whether it would be good or bad for women if their percentage on campuses went from 57 to 60 as seems possible in the not too distant future. The vast majority of my female students think it would be terrible. They know that more women and fewer men will make it still harder for them to find a good man ready to commit. Women still want to marry, and they want to marry men who are at least as educationally and professionally accomplished as they are. Perhaps we could encourage Women's Centers interested in outside the box thinking to sponsor forums on ways to get a higher proportion of men prepared for and interested in a college education. Leonard Sax and Christina Hoff Sommers could be asked to help on this project.

Religious Institutions The historic teachings of Christianity, Judaism and Islam all include a belief in sex differences, and their doctrines about sexuality are unfriendly to casual sex. Their institutions could do more than they now do to teach young women and young men about how casual sex harms both sexes, particularly women.

Parents It is with reluctance that I make unsolicited suggestions for what parents might say to their daughters about their relationships with men. Young women will have differing life plans and may or may not have boyfriends. Still, I wonder about the advice that parents give their graduating daughters who have boyfriends of whom the parents approve. My students tell me that the parents often advise their daughters to "not even think about getting married until you have a graduate degree and have begun your profession. With a $50 \%$ divorce rate it is too risky to get married right out of college." The first problem is that these parents have some facts wrong. The divorce rate for all Americans is not $50 \%$; it is more like $43 \%$. More importantly, it is much less for college graduates-about $33 \%$ of marriages to those without college degrees end in 10 years, while only about $11 \%$ to those with college degrees end in 10 years. The median duration of marriages for those who end up divorcing is 8 years, so that $11 \%$ is not likely to be doubled over the college graduates' lifetimes.

Marriages of couples who marry in their thirties are more likely to last than those that commence at an earlier age. But later marriage does not necessarily mean happier marriages. Husbands and wives who marry in their mid to late twenties are more likely to report that they are very happy than are those who marry at a later age. And marriages that are both stable and very happy are more likely to commence in the couple's early to mid-twenties than later.

Moreover, the 22-year-old woman in love with a boyfriend with "prospects" might not get another attractive proposal later. About fifty-seven percent of college graduates are women. This means that about 14 out of every 57 graduate women (just under $25 \%$ ) will not be able to marry a man who is also a college graduate, at least one who has not previously been divorced. And many women who don't marry until their early thirties will have sexual relations with and cohabit with men who will break up with them. The therapist Patricia Dalton has written of the difficulties she has with thirtyish female clients who are "acting like a wife" while their partners are "acting like a boyfriend."

Dalton is convinced that sex makes the breakups much harder on women. She acknowledges that, though she can perhaps help these women in some ways, "the emotional costs of breaking up over and over ... are hard to calculate." Dalton says she "can't magically restore the hope, optimism and innocence that these world-weary women have lost."

I wonder whether parents who advise their daughters to avoid marriage soon after college think about what dating and mating is likely to be like for their daughters between, say, 22 and 32. And, they may or may not think about the fertility pressures that the later marriage brings with it.

Women are deeply relational. Ninety percent of married women say their marriage makes them happy all or most of the time; only $60 \%$ say the same about their job.

Young Women Economists assume that we can tell what people like by their revealed preferences. Most of the time 
we can. If people take up tennis or softball and begin playing more, we can fairly assume that it is because they have come to enjoy those activities more. As argued above, this assumption doesn't work with casual sex for women. Townsend finds that adventurous, untraditional women who are initially attracted to casual sex, in time find that their feelings will not cooperate. It does not make them happy, and they become less and less inclined to participate as time goes by. Moreover, as unfair as it may seem, men who enjoy sex with lots of women usually prefer to marry women who have not had lots of sex with lots of men. (Evolutionists argue that men's aversion toward wives with promiscuous pasts runs deep because the aversion makes it more likely that they will not end up unwittingly raising other men's children).

Women who conclude that casual sex does or would make them unhappy can choose not to participate. But to get a more female friendly mating culture, they will need to unite with other women. Danielle Crittenden has argued that "if women as a group cease to be readily available - if they begin to demand commitment (and real commitment, as in marriage) in exchange for sex-market conditions, will shift in favor of women."

Women who participate in casual sex make it harder for the majority of women to get dates and committed sex. They make it harder for women to live in a world where they are courted and respected. We live in a very tolerant age, but this majority of women should feel free to try to protect their interests. Women who participate in casual sex impose external costs on the majority who would prefer a dating culture to a hookup one.

The majority are free to choose their friends from among their peers who do not impose costs on them. They should not feel guilty about protecting their interests, even if the women participating in serial hookups are making themselves happy (which seems unlikely given what I present above).

Groups that try to combat the hookup culture and create a more female friendly dating culture already exist on many campuses. I'm thinking of the Network of Enlightened Women $(\mathrm{NeW})$ and the Love and Fidelity network. NeW, for example, tries to encourage the better side of men by sponsoring a Gentlemen's Showcase, in which chapters nominate and campaign for their nominees to become the national network's outstanding gentleman of the year. The Love and Fidelity Network sponsors national and regional conferences where speakers and students discuss the benefits of love and fidelity.

These sorts of groups could do more. For example, during orientation week they could sponsor forums where upper class women explain the hookup culture to entering freshmen females. They could also approach women's centers in a friendly way, presenting the evidence about the effects of casual sex on young women. If women's centers refuse to take the issue seriously, the groups could picket the centers and take their concerns to the media or state legislatures.

Sexual mores are a "big deal." As Regnerus argues, the current ones lead to late marriages in which women cannot have as many healthy children as they would prefer. And, they also lead to too many children raised without the benefits of stable marriages of parents biologically connected to them.

Steven E. Rhoads is a Professor of Politics at the University of Virginia and the author of Taking Sex Differences Seriously and The Economist's View of the World. 